\title{
Limba română în Bucovina habsburgică din perspectiva bilingvismului instituționalizat
}

\author{
Ana-Maria Prisacaru ${ }^{\mathbb{R}^{\mathrm{R}} \star}$ \\ Institutul de Filologie Română „A. Philippide”, Str. Th. Codrescu 2, 700481 Iași, România
}

\section{Despre articol}

Istoric:

Primit 28 septembrie 2020

Acceptat 16 octombrie 2020

Publicat 27 decembrie 2020

Cuvinte-cheie:

Bucovina

Imperiul Habsburgic

bilingvism

reformare

germanizare

\begin{abstract}
Rezumat
Din perspectiva raporturilor de putere care se instituie într-un teritoriu de ocupație străină, bilingvismul instituționalizat presupune diferențierea statutului limbilor în contact și ierarhizarea acestora în funcție de atribuțiile comunicative care le vor reveni în cadrul noii organizări statale guvernate de o autoritate suzerană. Fenomen lingvistic inegal din punctul de vedere al funcționalităţii limbilor interferente, acest tip de bilingvism a generat și în Bucovina habsburgică impunerea limbii germane, declarată oficială în nordul moldav în anul 1784, ca singura limbă folosită în „oficiile țării”. Limitarea funcțiilor de comunicare ale limbii române aproape exclusiv la registrul colocvial este rezultatul amplei politici de „nivelare” lingvistică (Ausgleichspolitik), implementată de Curtea de la Viena în toate provinciile imperiale în vederea reducerii particularismului național prin obligativitatea cunoașterii și a folosirii limbii germane. Cum dezideratul coeziunii şi uniformizării tuturor teritoriilor habsburgice se putea atinge doar prin reformarea, în spirit iosefinist, a instituțiilor responsabile de păstrarea consțiinței identitare a națiunilor subjugate, în Bucovina au fost vizate în acest sens sectoarele juridico-administrativ, bisericesc și școlar, afectate de germanizare mai ales după încorporarea nordului Moldovei în Regatul Galiției și Lodomeriei.
\end{abstract}

\section{Introducere}

Anul 1774 marchează pentru nordul moldav ruperea de patria-mamă și anexarea la Imperiul Habsburgic. Actul anexionist este decis de Turcia, Austria și Rusia, cele trei mari puteri europene, într-un context politico-diplomatic complex, imediat după încheierea războiului ruso-turc (1768-1774) soldat cu înfrîngerea Porții Otomane. În schimbul ajutorului militar, Austria obține de la Înalta Poartă cedarea „cheii Moldovei” (der Schlüssel der Moldau), teritoriu care avea să fie numit ulterior Bucovina, considerat de Curtea de la Viena o punte de joncțiune între Transilvania, Maramureș și Galiția, numai bună pentru „a înlesni comunicațiile şi comerțul” și pentru „a procura debușeuri pentru trupe în caz de războiu, de la o provincie la cealaltă” (Kogălniceanu, 1911, p. 11).

La vremea anexării Bucovinei, politica de stat a Monarhiei de Habsburg era dominată de principiile doctrinei iosefiniste, care urmărea, pe de o parte, „centralizarea, uniformizarea” (Ceaușu, 1998, p. 26) tuturor teritoriilor habsburgice în spiritul intensificării coeziunii imperiului și, pe de altă parte, punerea sub controlul statului a tuturor domeniilor de activitate din provinciile anexate. Iniţial, în perioada administrației militare (1774-1786), Curtea de la Viena își respectă promisiunea de a păstra statu-quo-ul tradițional în Bucovina. Deși s-au făcut propuneri de reorganizare a provinciei încă de la sfîrșitul anului $1774^{1}$, Iosif al II-lea se arată prudent față de aceste sugestii, știut fiind că „poporul ține morțiș la vechile

*Adresă de corespondență: carpanamaria@yahoo.co.uk.

${ }^{1}$ Este vorba despre cele dintîi măsuri propuse Curții de la Viena de către primul guvernator al Bucovinei, generalul maior Gabriel Spleny von Mihaldy: „îndepărtarea moldovenilor din orice funcție administrativă sau juridică și înlocuirea lor cu ofițeri; subordonarea întregului aparat de stat guvernatorului militar, care să-și aibă sediul la Cernăuți; înființarea a două judecătorii, conduse de ofițeri și ajutați de cîte un «cancelist» german și doi moldoveni; rezolvarea tuturor problemelor de natură econo- 
Ana-Maria Prisacaru

sale datini și obiceiuri” (Nistor, 1991, p. 45). În condițiile în care se dorea sporirea demografică în teritoriul proaspăt alipit, emigrarea bucovinenilor în Moldova, nemulțumiți de modificări prea bruște, era de neconceput. Se decide, totuși, reducerea numărului de mănăstiri și trecerea pămînturilor și fondurilor acestora sub administrația statului.

$\mathrm{Nu}$ aceeași va fi soarta Bucovinei începînd cu anul 1786, cînd, în spiritul „centralismului” iosefinist, care urmărea fuzionarea anumitor provincii învecinate din considerente de ordin mai ales economic, nordul Moldovei va fi alipit la Regatul Galiției și Lodomeriei. Este perioada unor profunde restructurări politico-administrative, bisericești și școlare, toate vizînd germanizarea, reforme care zdruncină implicit statutul limbii române ca limbă oficială în Bucovina. Sub administrație civilă, teritoriul moldav va fi subordonat, finalmente, aceluiași regim de guvernare implementat în toate provinciile imperiale, reprezentat, la nivel lingvistic, de cunoscuta politică de „nivelare” (Ausgleichspolitik), prin care Casa de Habsburg „se străduia să atenueze contradicțiile și disputele etnice, propovăduind renunțarea la particularitățile naționale” prin „abandonarea limbilor naționale și folosirea uneia singure, cea a Vienei, limba germană” (Moldoveanu, 1998, p. 224).

\section{Bilingvism instituționalizat în Bucovina habsburgică}

Impunerea limbii germane ca limbă oficială în Bucovina începînd cu anul 1784 creează contextul apariţiei bilingvismului instituționalizat, fenomen specific teritoriilor de ocupaţie străină, reflectînd raporturile de putere și presupunînd „un statut diferențiat al limbilor în contact, diferențiere derivînd din rolul pe care organizarea de stat îl atribuie fiecăreia dintre ele” (Guţu-Romalo, 2004, p. 34). Plecîndu-se de la premisa că cel care nu vorbește și limba Imperiului „va deveni un om rău învățat și absolut de neîntrebuințat pentru stat" (Aurel Morariu, Bucovina (1774-1914), p. 39, apud Moldoveanu, 1998, p. 20), limba germană ajunge să guverneze ierarhia generată de acest tip de bilingvism inegal, devenind utilizată cu precădere în toate instituțiile cu rol esențial în conservarea identității naționale a bucovinenilor: justiție, administrație, școală și biserică. Restrîngerea funcționalității limbii române aproape exclusiv la registrul colocvial are drept urmare acceptarea ei, în contextul bilingvismului instituționalizat, doar cu „statut de idiom «secundar», îngrădit în realizarea funcțiilor sale comunicative prin limitarea atribuțiilor sociale în interiorul structurii statale în care funcționează” (Chivu, 2004, p. 36).

Bilingvismul instituționalizat nu afectează mediul rural, unde româna continuă să fie singura limbă vorbită în familie. În mediul urban, însă, atît limba germană, intens folosită în administraţie, comerț și meșteșuguri, cît și limba polonă, limba imigranților galițieni, subminează statutul limbii române. Amăgiți de echivalarea rangurilor boierești cu ranguri nobiliare imperiale, destui boieri români aderă la Forumul nobiliar al Bucovinei (Forum Nobilium, creat în 1804), deși nu vor beneficia de aceleași privilegii ca ale omologilor galițieni. Cu toate acestea, în multe cercuri de nobili se adoptă nu numai în chestiuni oficiale, ci și în familie limba germană și limba polonă, ultima fiind considerată „la modă” și vorbită, așadar, din dorința de a epata. Aculturația care se încuibă în sînul „păturii culte a societății” și care generează „o românească stricată, cu construcții și fraze urmînd îndeaproape modelele germane” (Moldoveanu, 1998, p. 126) este favorizată și de învățămîntul secundar și superior utracvist, mulți dintre elevi nereușind să stăpînească bine nici limba română, nici pe cea germană: „cînd vorbesc sau scriu românește, e plin scrisul și vorba lor de germanisme, iar cînd vorbesc și scriu nemțește, întrebuințează fraze românești” (Greciuc, 1912, p. 32). Se ajunge, astfel, la situația creionată de Ion Nistor (1916, p. 11), anume că limba română curată ,își găsi singurul adăpost în casa țăranului [...] şi la curtea puținilor boieri care mai rămăseseră în Bucovina”. Situația nu este, însă, atît de gravă ca în Basarabia țaristă, unde politica agresivă de rusificare a urmărit discreditarea limbii române și, pe cît posibil, anularea funcționalității ei în contextul sociocultural $^{2}$ :

mică, social-politică sau culturală și religioasă de către comandantul militar al zonei, ajutat de un comitet de ofițeri” (Iacobescu, 1993, p. 117).

${ }^{2}$ Aici, politica lingvistică atinge o extremă critică prin crearea glotonimului de ‘limbă moldovenească, desemnînd o limbă 
Românii „moldoveni”, forțați, printr-o intensă propagandă, să constate caracterul „țăănesc”, „necivilizat” al limbii lor materne, au fost constrînși să accepte chiar pentru conversația zilnică, dacă nu integral limba rusă, cel puțin influențe semnificative ale acesteia. Deznaționalizarea a devenit astfel, din politică de stat, opțiune culturală individuală (Chivu, 2004, p. 81)

\section{Limba română în Bucovina habsburgică din perspectiva reformării juridico-administrative}

În momentul anexării, nordul moldav purta amprenta românității: populația era majoritar românească și limba vorbită preponderent era româna, fapt confirmat de Ion Budai-Deleanu (1813, p. 385), care menționează că graiul bucovinenilor este „vechea limbă romană populară, amestecată cu felurite cuvinte slavone, grecești și albaneze, dar cuvintele luate din alte limbi abia fac o treime”. În prima etapă a guvernării habsburgice, în care s-a promis cruțarea conștiinței identitare a bucovinenilor, limba română a avut de facto un statut egal cu cel al germanei. Dovadă stă faptul că toate actele publice și oficiale de la acea vreme erau tipărite fie în română, fie bilingv. Ion Nistor inventariază 96 de foi volante adresate bucovinenilor, toate redactate bilingv. În chestiuni judecătorești, toate hotărîrile emise de instanțe, prin care se soluționează cererile înaintate de bucovineni, sînt formulate în română. Mai mult, toți funcționarii imperiului, inclusiv cel de-al doilea guvernator al Bucovinei, generalul Enzenberg, sînt învestiți în funcții cu condiția să vorbească și românește. Ulterior, însă, acest primat al limbii române este încălcat, deoarece era greu de admis ca „,̂ntr-o singură provincie legile și afacerile publice să fie tratate în limba naţională” (Torouțiu, 1916, p. 44).

Primul afectat de procesul germanizării, cu repercusiuni și în plan lingvistic, a fost sectorul juridicoadministrativ. Reformarea începe cu pași mici, părînd a fi favorabilă menținerii statutului limbii române. De menționat este faptul că, inițial, Iosif al II-lea cere ca pozițiile-cheie din organizarea administrativă, acelea de director și ispravnic de district, să fie ocupate de funcționari aduși din Banat și Transilvania, pentru că aceștia știau atît germana, cît și româna. Ba chiar Consituția austriacă a fost tradusă în română, în 1786, pentru a fi accesibilă moldovenilor. Ulterior, însă, „sensibilă” la pretextele invocate de Spleny, anume că moldovenii care îndeplineau funcții juridico-administrative cunoșteau doar „obiceiul pămîntului și legile românești” și erau „aflați sub influența bisericilor și preoților” (Iacobescu, 1993, p. 116), Curtea de la Viena a recurs la marginalizarea acestora sau la înlocuirea lor cu funcționari străini, deoarece, în realitate, avea nevoie de supuși ai imperiului, adepți ai ideilor reformatoare iosefiniste. Restructurarea juridicoadministrativă ia amploare mai ales după alipirea Bucovinei la Galiția, prielnică pentru „imigrația slavă [și] importul de funcționari galițieni” (Ștefanelli, 1911, p. 29). Cum toți acești slujbași străini nu cunoșteau limba română, urmarea firească a fost impunerea germanei ca singura limbă folosită în acest domeniu. La începutul secolului al XIX-lea, cînd guvernul de la Viena adoptă o nouă reformă pentru „unirea credinței grecești-ortodoxe a popoarelor orientale cu biserica glorios dominantă romano-catolică” (vezi infra), apare o nouă piedică pentru moldovenii aspiranți la funcții administrative: pe lîngă cunoașterea limbii germane și instruirea în școli germane, aceștia trebuie să se convertească la catolicism. În aceste condiții, sursele istorice consemnează faptul că, la 1910, aparatul juridico-administrativ era reprezentat de doar 87 de români dintr-un total de 627 de funcționari (cf. Iacobescu, 1993, p. 267).

\section{Limba română în Bucovina habsburgică din perspectiva intercondiționării reformelor ecleziastice și școlare}

Implicaţii mult mai severe asupra statutului limbii române în Bucovina au avut restructurările operate de habsburgi în domeniile ecleziastic și școlar, deoarece coeziunea provinciilor imperiale era posibilă doar prin etatizarea bisericii și printr-o elaborată reformă educaţională, gîndită „să restrîngă particularismul național local”, dar și să asigure bucovinenilor, prin școală, „un minim de cultură și de educație moral-civică, 
menite să sporească valoarea și gradul de utilitate în stat" (Ceaușu, 1998, p. 119, 232). Intercondiționarea reformării celor două sectoare are ca prim punct de plecare închiderea lăcaşurilor de cult și secularizarea averilor mănăstirești. În anul 1783, din considerente de factură politică și economico-financiară, Iosif al II-lea dispune ca din cele 17 mănăstiri, 15 schituri și 4 sihăstrii din Bucovina să mai rămînă deschise doar mănăstirile Putna, Sucevița și Dragomirna, fiecare cu maxim 25 de călugări. Cum clerul bucovinean era în subordinea Mitropoliei de la Iași și, prin urmare, întreaga avere mănăstirească obținută de pe cele 267 de proprietăți lua drumul Moldovei, Curtea imperială decide în același an subordonarea bisericii bucovinene in dogmaticis et mere spiritualibus față de Mitropolia sîrbească de la Carloviț, după ce în 1781 hotărîse, ca o primă măsură de separare față de clerul din Moldova, înființarea unei episcopii autonome în Bucovina.

Reforma ecleziastică este continuată de constituirea Fondului Religionar Greco-Oriental al Bucovinei, cunoscut drept Fondul Bisericesc, cu scopul declarat ca din veniturile mănăstirești să se întrețină preoții ortodocși și personalul bisericesc, să se formeze preoți învățați și să se înființeze școli publice în fiecare sat unde exista o parohie. În 1786, însă, acest fond este scos de sub supravegherea Consistoriului Ortodox, care va avea de acum dreptul să se pronunțe doar în chestiuni care „ating dogma și cele curat spirituale” (Nistor, 1921, p. 20), și este trecut în administrarea Galiției, ajungînd să deservească școli catolice cu predare în limba germană și polonă.

Limba română, despre care se stipulase în Regulamentului bisericesc (sau Planul de regulare pentru mănăstirile și școlile din Bucovina) din 1786 că trebuie să fie „limba oficială a eparhiei, precum și a oficiului religios în cadrul ei” (Moldoveanu, 1998, p. 19), își pierde această funcție după încorporarea Bucovinei în Galiția. Îngrijorată de puternica influență pe care biserica ortodoxă o are asupra bucovinenilor, influență resimțită drept o amenințare la adresa politicii de germanizare, Curtea de la Viena, ghidîndu-se după principiul divide et impera, favorizează răspîndirea catolicismului prin construirea de biserici romanocatolice pentru coloniștii germani şi greco-catolice pentru rutenii și huțulii imigrați din Galiția. Strategia culminează în vremea lui Daniil Vlahovici, numit episcop al Bucovinei după moartea lui Dosoftei, prin elaborarea Planului cum s-ar putea aduce în sfirșit la îndeplinire unirea credinței grecești, ortodoxe, a popoarelor orientale cu biserica glorios dominantă, romano-catolic $\breve{a}[. .$.$] , plan care urmărea atragerea ortodocșilor$ bucovineni la confesiunea dominantă a Imperiului Habsburgic. Deși românii nu au renunțat niciodată la religia lor, toate aceste măsuri au avut rostul de a spori intruziunea Curții de la Viena și în viaţa religioasă din Bucovina, obiectivele principale fiind punerea bisericii sub controlul statului și, implicit, reducerea atribuțiilor clericilor români doar la chestiuni religioase, aceștia nemaiavînd putere de decizie asupra gestionării fondului bisericesc și a organizării sistemului românesc de învățămînt.

Surse istorice străine (Ferdinand Zieglauer, R.F. Kaindl, Johann Polek, Erick Prokopowitsch ș.a.) consemnează faptul că, în momentul anexării, Bucovina dispunea de o rețea școlară precară. Elocvente în acest sens sînt mențiunile lui Polek (1899, p. 126):

Cultura spirituală a locuitorilor se afla la nivelul cel mai de jos. Existau, e drept, cîteva școli mănăstirești, la Putna, Rădăuți și Suceava; dar ele aveau, totuși, numai scopul să-i învețe pe candidații la preoție cunoștințele strict necesare pentru activitățile serviciului divin. Marea masă a poporului creștea fără nici o învățătură.

Fără a contesta impactul covîrșitor pe care l-au avut reformele imperiale asupra dezvoltării învățămîntului românesc, trebuie amintit totuși faptul că în Moldova funcționau, încă din 1766, școli domnești la Putna, Siret, Suceava, Cernăuți, Rădăuți și Cîmpulung Moldovenesc și că școli primare, deși rudimentare, existau în multe tîrguri și sate, dar și pe lîngă mănăstiri. Primul pas spre modernizarea și germanizarea sistemului educațional îl reprezintă învățămîntul bilingv: încă din 1774, Spleny propune înființarea la Suceava a unei școli româno-germane, care să asigure pregătirea bucovinenilor aspiranți la funcții administrative. Urmează, în 1780, decizia Consiliului Aulic de Război de a se înființa „nu numai școli valahice, ci și germane” măcar în Cernăuți, Suceava și Siret (Iacobescu, 1993, p. 279), la care să se înscrie nu doar copiii coloniștilor germani, ci și copii români. Ca atare, în 1784 se deschid două școli normale germano-române 
la Cernăuți și Suceava. Acestora le urmează școlile de la Zastavna, Vășcăuți, Cîmpulung pe Ceremuș, dar și școli triviale care funcționează pe lîngă parohiile sătești, toate teoretic cu predare în limba română ${ }^{3}$, aflate sub supravegherea Consistoriului Ortodox din Cernăuți și finanțate din fondul bisericesc. Astfel, între 1786 și 1792, în Bucovina se înregistrează 32 de școli $^{4}$, situație favorabilă școlarizării tuturor bucovinenilor doritori de carte, însă din 1793, cînd se suspendă obligativitatea învăţămîntului din motive financiare, multe dintre acestea se închid. În 1804, spune Iacobescu (1993, p. 282), mai erau active doar 14 şcoli „care propagau limba şi cultura germană, catolicismul și conservatorismul imperial”, iar din 1816, cînd învățămîntul intră sub controlul Consistoriului Catolic din Lemberg, situația se agravează și mai mult, deoarece în școli este introdusă și limba polonă. În plus, șansa învăţătorilor români de a mai preda în școlile din Bucovina scade dramatic în condițiile în care, pe lîngă cunoașterea limbii germane, devine obligatorie convertirea la catolicism, religie majoritară în Galiția. Deși inițial Iosef al II-lea a cerut ca în nordul moldav școlile să aibă „o temelie curat națională și confesională” (Iacobescu, 1993, p. 286) și predarea să se facă de către cadre didactice care să știe românește, învățătorii români sînt treptat înlocuiți cu străini, cei mai mulți preoți catolici veniți din Galiția, necunoscători ai „limbii țării”. Locul limbii române în sistemul școlar din perioada administrației civile ajunge să fie uzurpat de limba germană, limba oficială a Imperiului, dar și de limba polonă, limba oficială a provinciei galițiene. Drept dovadă stă o ordonanță din 1824 a guberniului galițian, unde se stipulează ca limba română „să se întrebuințeze numai atîta cît este de trebuință spre explicarea lecției propuse" (Bogdan-Duică, 1895, p. 55). Nu este de mirare că bucovinenii, în profund dezacord față de această politică de deznaționalizare, nu-și mai trimit copiii la școlile unde învățătorii nemți sau polonezi nu le vorbesc în limba maternă. La toate acestea se adaugă și faptul că din 1805 învățămîntul primar capătă caracter confesional. Cu alte cuvinte, școala este ortodoxă sau catolică în funcție de confesiunea preotului din localitate. Această dispoziție imperială este nefavorabilă ortodoxismului, dacă ținem cont de ponderea străinilor catolici care se strămutaseră în numeroase așezări bucovinene. Mai grav, în încercarea de a aplica acel Plan de fuzionare a ortodoxismului cu „biserica glorios dominantă, romano-catolică” (vezi supra), școlile primare românești sînt declarate în 1815 școli confesionale catolice, subordonate Consistoriului Romano-Catolic din Lemberg, însă susținute tot din acel fond bisericesc destinat inițial dezvoltării sistemului școlar pur românesc. Această din urmă măsură a generat „lichidarea aproape totală a rețelei școlare românești, prin înlăturarea învățătorilor și a profesorilor români, prin înlăturarea limbii și a culturii naționale din cadrul acestora" (Iacobescu, 1993, p. 298).

Revoluția de la 1848 înregistrează o izbîndă notabilă pentru învățămîntul românesc, deoarece, odată cu înființarea școlii normale de la Cernăuți pentru „preparandia” viitorilor dascăli din Bucovina, Limba și literatura română se reintroduce ca obiect de studiu. Această primă victorie este urmată de decizia Curții imperiale de a se introduce limba română, ca limbă de predare, și la Institutul Teologic din Cernăuți, dar și de înființarea unei catedre de limbă română la liceul german din Cernăuți. Învăţămîntul va reveni sub supravegherea Consistoriului Ortodox abia în 1850, ocazie cu care școlile la care învățau copiii români își vor recăpăta caracterul ortodox.

\footnotetext{
${ }^{3}$ Printr-o decizie din 1783 a Consiliului Aulic de Război se hotăra ca învățătorii, mulți aduși din Transilvania, „să cunoască, pe lîngă limba germană și latină, limba țării, adica limba românească” (Nistor, 1991, p. 275). Această condiție este adesea încălcată dacă ținem cont că în școlile bucovinene vor activa dascăli precum Franz Thaillinger, figură importantă în cadrul școlii normale de la Suceava, care însă nu știa deloc românește. La școala clericală de la Mănăstirea Sf. Ilie din Suceava, care avea menirea de o forma preoți ortodocși și era finanțată din fondul bisericesc, materiile se predau în germană și director a fost numit sîrbul Daniil Vlahovici.

${ }^{4}$ Este vorba despre: şcoli normale, unde se formau viitorii funcționari administrativi și învățătorii pentru școlile triviale, școli principale, la care aveau acces copiii înstăriți în ideea instruirii pentru funcții administrative secundare, dar și şcoli triviale, menite să asigure cunoștințe elementare de scris, citit și socotit copiilor din mediul rural, deoarece o preocupare constantă a politicii iosefiniste a fost ridicarea, prin cultură, și a păturii de jos a societății.
} 


\section{Concluzii}

Deși în toată perioada de ocupație habsburgică limba română a avut statut de limbă oficială în Bucovina, reformele operate de Curtea de la Viena în vederea reducerii particularismului național—reforme aplicate nu doar aici, ci în toate provinciile imperiale — vor avea drept consecință înlăturarea ei din toate instituțiile responsabile de păstrarea conștiinței identitare a bucovinenilor. Politica iosefinistă de „nivelare” lingvistică (vezi supra) s-a înfăptuit, pe de o parte, prin restructurarea aparatului juridico-administrativ, acaparat, mai ales după încorporarea Bucovinei în Galiția, de funcționari străini, care nu știau limba țării, astfel încît cunoașterea și folosirea limbii germane au devenit obligatorii în acest domeniu. În urma etatizării bisericii, Curtea imperială va avea putere absolută de decizie asupra administrării averii ecleziastice și a organizării sistemului școlar.

$\mathrm{Cu}$ toate că este indiscutabilă deschiderea culturală facilitată românilor din Bucovina prin implementarea reformelor imperiale, regretabil este faptul că limba română, deși oficială, a rămas mult timp doar ca limbă de predare a orelor de religie în unele școli. Din perspectiva raporturilor de putere, accesul bucovinenilor nu doar la structurile juridico-administrative, ci și la școlarizare de calitate este condiționat de însuşirea și folosirea limbii Imperiului. Pînă cel puțin în 1869, cînd, printr-o hotărîre imperială, „împărăția recunoaște că toate limbile unei țări sînt egal îndreptățite în școli, diregătorii și în viața de obște" (Moldoveanu, 1998, p. 112), învățămîntul secundar și superior funcționează sub monopolul limbii germane, în vreme ce învățămîntul primar este marcat de infiltrarea limbii polone. Începînd cu perioada în care teritoriul bucovinean dobîndește autonomie provincială, ca ducat, limba română va cîștiga teren în exercitarea funcțiilor sale comunicative în toate „oficiile țării” mulțumită eforturilor susținute ale intelectualităţii românești de la acea vreme. Însă reconfirmarea ei ca singura limbă oficială folosită în nordul moldav va surveni în 1918, odată cu unirea Bucovinei cu România.

\section{Bibliografie}

Bogdan-Duică, G. (1895). Bucovina - notițe politice asupra situației, Institutul Tipografic T. Liviu Albini, Sibiu.

Budai-Deleanu, I. (1813). Scurte observații asupra Bucovinei, în Bucovina în primele descrieri geografice, istorice, economice și demografice, ediție îngrijită de Radu Grigorovici, Editura Academiei Române, București, p. 373-429.

Ceaușu, M.-Șt. (1998). Bucovina habsburgică de la anexare la Congresul de la Viena. Iosefism și postiosefism (1774-1815), Fundația Academică „A. D. Xenopol”, Iași.

Chivu, Gh. (2004). Limba oficială din Republica Moldova și unitatea culturii românești, în Grecu, A. (ed.), Unitatea limbii române, cu privire specială la Basarabia și Bucovina, Editura Academiei Române, București, p. 79-87.

Greciuc, V. (1912). Utracvismul sau două limbi de predare la liceele (gimnaziile) românești din Bucovina, Tip. Soc. "Școala Română”, Cernăuți.

Guțu-Romalo, V. (2004). Evoluția limbii române în Republica Moldova, în Grecu, A. (ed.), Unitatea limbii române, cu privire specială la Basarabia și Bucovina, Editura Academiei Române, București, p. 33-48.

Iacobescu, M. (1993). Din istoria Bucovinei, Vol. I (1724-1862). De la administrația militară la autonomia provincială, Editura Academiei Române, București.

Kogălniceanu, M. (1911). Răpirea Bucovinei, ediția a 2-a, Editura „Neamul Românesc”, Vălenii de Munte.

Moldoveanu, Gh. (1998). Limba română în Bucovina. Statutul socio-cultural și politic, Editura A92, Iași.

Nistor, I. (1916). Un capitol din vieața culturală a românilor din Bucovina, 1774-1857. Discurs rostit la 21 maiu (3 iunie) 1916 în sedință solemnă de I. Nistor, cu răspuns de N. Iorga, în Academia Română. Discursuri de recepțiune, vol. 44, Librăriile Socec et Co., C. Sfetea, Pavel Suru, București, p. 3-64.

Nistor, I. (1921). Istoria fondului bisericesc din Bucovina, Institutul de Arte Grafice și Editura „Glasul Bucovinei”, Cernăuți.

Nistor, I. (1991). Istoria Bucovinei, ediție nouă, Editura Humanitas, București.

Polek, J. (1899). Die Besitzergreifung, in Die Österreichisch-ungarische Monarchie in Wort und Bild: Bukowina (Band 20.), Viena, p. 116-127.

Ștefanelli, T.V. (1911). Istoricul luptei pentru drept în ținutul Cîmpulungului-Moldovenesc, Librăria Socec \& Comp., București. Torouțiu, I.E. (1916). Poporația și clasele sociale din Bucovina, Editura Lupta, București. 